\title{
The Factors Influencing the Employment of Producer Services-From the Perspectives of Demand and Supply
}

\author{
Hui Jia, Baocheng Liu, Jia Li \\ School of Economics and Management, Beijing Institute of Petrochemical Technology, Beijing, China \\ Email: jiahui@bipt.edu.cn
}

How to cite this paper: Jia, H., Liu, B.C. and $\mathrm{Li}, \mathrm{J}$. (2019) The Factors Influencing the Employment of Producer ServicesFrom the Perspectives of Demand and Supply. American Journal of Industrial and Business Management, 9, 1666-1681. https://doi.org/10.4236/ajibm.2019.98109

Received: August 1, 2019

Accepted: August 16, 2019

Published: August 19, 2019

Copyright () 2019 by author(s) and Scientific Research Publishing Inc. This work is licensed under the Creative Commons Attribution International License (CC BY 4.0).

http://creativecommons.org/licenses/by/4.0/

\begin{abstract}
There exist strong direct and indirect employment contributions in producer services, which have become an important way to solve the employment problems in developed countries. In contrast, the overall employment ratio of producer services is low in China. It is important and necessary to study the influencing factors of producer services employment in order to fully explore the employment growth potential of producer services and promote the solution of current structural employment difficulties in China. This paper analyzes the conditions, under which the development of producer services drive the employment growth from the perspectives of demand and supply. The theoretical model of the influencing factors of producer services employment is constructed and the empirical method is adopted to measure the influencing effects of these factors. It is helpful for policy makers to grasp the key of producer services employment at the implementation level, so as to more actively and effectively defuse the negative impacts of economic recessions on the employment and alleviate the current employment pressures in China.
\end{abstract}

\section{Keywords}

Producer Services, Employment, Influencing Factors

\section{Introduction}

With the rapid development of service industry on a global scale, some developed countries have entered the era of service economy. One of the obvious trends is that the proportion of consumer services is decreasing and the proportion of producer services is increasing. The growth rate is not only higher than the average growth rate of the service industry, but also much higher than the 
average growth rate of the national economy. Producer services are dependent on the manufacturing industry. With intellectual capital and human capital as the main inputs, they can greatly reduce transaction costs, effectively transfer technology and professional knowledge, and significantly improve the efficiencies of productions and services, which play a powerful role in promoting modern economic growth. With the rapid expansion of its total amount and continuous optimization of its structure, the potential of producer services to promote employment has been fully released. At present, producer services have become one of the most important forces to solve the employment problems in developed countries. Some developing countries also give play to their advantages of backwardness and take the adjustment of the service sector, especially the development of producer services, as the focus of improving the core competitiveness of the industry and promoting employment.

There exist strong direct and indirect employment contributions in producer services, as well as strong employment growth potential [1]. The source of employment growth is industrial development, and the demand growth for labor is derived from the demand growth for producer-service products and the development of producer services. Compared with developed countries, the overall level of producer services in China is relatively backward, and the effective demand for producer services is insufficient. There are many obstacles to transform the huge potential demand into real demand. The market supply influences the development of producer services and the supply of jobs by guiding the demand. The problem of the demand naturally passes to the supply. The lack of effective demand and supply of producer services restrict producer services to play a role in stimulating employment. In order to fully explore the employment growth potential of producer services, it is important and necessary to study the influencing factors of producer services employment.

The main contribution of this paper is to analyze the influencing factors of producer services' development and employment growth from the perspectives of demand and supply, explore the conditions that drive employment growth, construct the factors model that affects producer services' employment, and measure the influencing effects of these factors by empirical methods. It is helpful for policy makers to grasp the key of producer services employment at the implementation level, so as to more actively and effectively defuse the negative impacts of economic recessions on the employment in China.

\section{Literature Review}

Aimed at the employment absorption effects, Kuznets (1960) found through empirical research that the employment effects of the tertiary industry were very significant [2]. Beyers (1999) showed that from 1977 to 1996, the employment growth of producer services in the United States and Canada was twice and 3.7 times that of the overall employment growth, contributing to the new employment by $1 / 4$ and $1 / 3$ respectively, making it the sector with the strongest em- 
ployment absorption capacity [3]. Juleff and Walker (1999) studied the employment structure of producer services in the UK using the data from 1971 to 1989, and found that the employment of the primary and secondary industries declined in absolute terms, while the employment of the service industry increased, among which the employment of producer services increased more than 3 times that of other services [4].

Aimed at factors influencing the employment of producer services, Bishop (2009) argued that knowledge spillover was an important factor affecting the employment absorption of producer services [5]. Lu Liwei (2010) analyzed the employment absorption capacity of producer services in the Yangtze River Delta Region, and found that the improvement of the employment absorption capacity of producer services should be achieved by adjusting the layout of producer services, promoting service trade and outsourcing, and establishing multi-level development coordination mechanism between enterprises and governments [6]. Taking Beijing as an example, Che Fang and Che Guangji (2012) conducted an analysis by using the panel data model and found that the urbanization level had the greatest impact on the employment in producer services, followed by the investment level and technical progress, and the wage level had the lowest impact [7]. Zeng Shihong and Ma Ming (2013) studied the factors influencing the employment absorption capacity of producer services under the background of China's high economic growth, and found that the proportion of state-owned enterprises in producer services and industrial wage level hindered the employment absorption of producer services [8]. Zhang Yanji et al. (2017) studied the spatial agglomeration and influencing factors of producer services in Beijing, and found that the enterprises and employment of high-end producer services were highly clustered on a small scale, while on a large scale, the ranking of industry agglomeration degree of enterprises and employment was not consistent [9]. The research of Li Lianshui et al. (2018) showed that "Internet+" could promote the employment of producer services when controlling such variables as industrial structures, capital inputs, local barriers, economic development level and environmental regulations [10].

In addition, many scholars have explored the reasons for the lagging development of producer services from the perspective of demand. Lv Zheng et al. (2006) held that the lack of effective demand for producer services was caused by the backward mode of industrial production in China [11]. Gao Chuansheng et al. (2007) found that the international OEM model of China's industry and the lack of upgrading incentives for industrial enterprises also limited the demand for relevant producer services to a certain extent [12]. Li Jiangfan (2005) summarized the factors affecting the demand for producer services as economic systems, the degree of specialization, enterprises property rights systems, the intensity of competition, the service quality of service enterprises, the prices of service, the economic development level and the degree of economic openness [13].

However, the existing researches have not yet paid attention to the obstacles 
of producer services from potential demand to real demand. These obstacles restrict the development of producer services and inhibit their functions of stimulating employment. The existing researches also fail to notice the restriction on employment caused by the problems in the supply of producer services in China. Therefore, based on the economic and social background of China's service industry development, this paper fully considers the potential demand for producer services to transform into real demand. Meanwhile, from the perspectives of demand and supply, the theoretical model of the influencing factors of producer services employment is constructed, and the empirical method is adopted to measure the influencing effects of these factors. It is helpful to fill the research gap in this field and promote the solution of the current employment problems.

\section{The Influencing Factors of Producer Services Employment from the Perspective of Demand}

According to the theory of market economy, the market demand is the core of industrial development. The increase in demand for labor is due to the increase in demand for producer services. At present, China has a huge potential demand for producer services, but it is difficult to transform the potential demand into the real demand. The restrictive factors mainly come from four aspects, including economic development mode, institutional factors, market mechanism, and related policies and regulations.

1) The Economic Development Pattern Restricts the Development and Employment of Producer Services. Firstly, the decentralized management model of the primary industry weakens the demand for producer services. Producer services are the intermediate demand. Due to the low level of organization and backward production mode, the primary industry has insufficient intermediate demands for producer services. Secondly, from the perspective of the secondary industry, the high resource-consumptive and factor-driven economic development mode and the low-grade industrial structure have greatly inhibited the demand for producer services and job creation. Finally, the demand for producer services by the service sector itself accounts for about one third of the total demand for producer services. Both the real demand and potential demand of producer services are mainly driven by the secondary industry, especially the manufacturing industry. The service industry attaches great importance to the quantitative industrial expansion, ignoring the improvement of the overall quality level. It emphasizes hardware over software, lacks service functions, has a low level of industrial development, and is still at a low level in both quality and quantity of demand for producer services. The job creation, especially high-end jobs with knowledge and technology content, is restricted.

2) The Institutional Barriers Prevent the Potential Demand From Transforming into the Real Demand. Institutional barriers mainly refer to the problems existed in the management system of resource ownership and allocation at the macro level, including three aspects: Firstly, the growth of demand and em- 
ployment is constrained by the concept of "Value the Secondary Industry over the Service Sector". It is believed that the contribution of service industry in value creation is weaker than that of the secondary industry. The concept of non-value creation or low value creation dominates many people's thinking and becomes a major obstacle to the growth of producer services demand and employment. Secondly, the growth of producer services demand and employment is constrained by the institutional obstacles of producer services outsourcing. At present, the quantity of producer services outsourcing of enterprises in China is insufficient, and the outsourcing level is low. Most of them are traditional producer services, such as transportations and logistics. In terms of "quality" and "quantity", the demand for producer services is relatively limited, and the growth of market-oriented producer services enterprises is limited due to the lack of real demand. Thirdly, the demand growth and the employment growth are constrained by monopolies. Administrative monopoly and natural monopoly reinforce each other and consolidate the monopoly position of large scale state-owned enterprises (postal telecommunications, railway and civil aviation, etc.). On the one hand, monopoly enterprises have poor outsourcing consciousness, and on the other hand, market price mechanism is difficult to play its role. The low quantity, poor quality and high price of services greatly inhibit the potential demand for producer services from being transformed into the real demand, making it unable to exert its effects of driving employment growth.

3) The Market Mechanism Prevents the Potential Demand From Transforming into the Real Demand. At present, Chinese producer services market remains strong market mechanism barriers, such as disorderly competitions, lack of standards, norms and integrity mechanisms, resulting in high market transaction costs. The difficulty of transforming the potential demand into the real demand greatly restricts the creation of jobs in producer services. A sound credit system environment is crucial to the development of producer services. The current market integrity mechanism is far from being established, which makes the transaction costs of producer services increase substantially. The lack of market integrity leads to the lack of high-end service products, the difficulty in standardized operations of the market, and the information asymmetry between supply and demand is an important reason for the high transaction costs and insufficient demands. The reduction of transaction costs in service market in developed countries is generally realized through the call and influences of brand enterprises and the self-disciplines of industry associations. At present, China is weak on both counts.

4) Some Policies and Regulations Restrict the Development and Employment of Producer Services. Firstly, the existed tax system has not played a good role in encouraging, supporting and stimulating the demand for producer services. The tax burden of producer services is relatively heavy, and the tax elasticity coefficients are higher than those of the manufacturing. There are some problems in the tax policy, such as uneven tax burdens among sub-industries af- 
ter the scope of value-added tax is expanded, enterprises' income tax tends to be directly preferential and has no obvious guidance, and individual income tax lacks encouragement for human capital investment. Secondly, there is a lack of industrial support policies related to producer services, which are insufficient to guide and stimulate the demand for producer services, which restricts their own development and employment growth. Especially in China, there is not enough guidance and support for the brand building of the service industry, especially producer services with high output efficiency, and there is a lack of relevant supporting policies for the cultivation of "Model Producer Services Enterprises", and the relevant work is still weak, which constrains their own development and employment.

\section{The Influencing Factors of Producer Services Employment from the Perspective of Supply}

The developed supply market of producer services can be cultivated and formed only when certain economic and social conditions are available. The current situations of producer services in China is that the upper and middle reaches of the industry are developing slowly, and the proportion of the downstream industry in GDP is decreasing year by year, that is, the effective supply is insufficient. The restriction mainly comes from the institutional factors, the policy factors and the technical progress.

1) The Strict Government Regulations and Interventions Constrain the Supply Expansion and Employment of Producer Services. At present, there are still prominent administrative monopoly problems in service industry of China. Most producer services are monopolistic competitive industries with dual characteristics of monopoly and competitive industry. Monopoly mainly includes natural monopoly, market monopoly and administrative monopoly. We are firmly opposed to administrative monopoly, because it seriously affects and inhibits the externalization and professional development of producer services, strangles market competitions and restricts the improvement of industrial efficiencies. In addition, strict government regulations and interventions seriously inhibit the improvement of producer service supply and the creation of jobs. For some sub-industries of producer services, China mainly has relatively strict access control, such as the financial industry and telecommunications industry. The prices of producer services such as finance, transportation and information are mainly set and managed by the government. The high prices greatly restrict the real demand for producer-service products and also restrict the power of service supply.

2) The Disharmonies Between Policy Objectives Restrict the Growth of Producer Services Supply and Employment. Firstly, the formulation and implementation of the policy for the development of the service sector aimed at expanding employment is unfavorable to the long-term development and employment of the producer service industry. Producer services at the high-end of 
the value chain have higher productivity, so they have limited ability to absorb low-end workers. However, when formulating industrial development policies, many local governments overemphasize the employment functions of the industry and neglect its efficiency functions. As a result, a large number of resources flow to labor-intensive sub-industries, such as residential services, accommodation and catering services. To some extent, this restricts the supply of producer services of high productivity and long-term employment is constrained. Secondly, urbanization policies in China affect the development of producer services and employment. By the end of 2017, Chinese urbanization rate had reached $58.52 \%$, and was expected to increase to $65 \%$ to $70 \%$ by 2030 [14]. However, the internal structure of the service industry has not changed qualitatively, and the proportion of producer services in the service industry is much lower than that in developed countries. The cause of the problem lies in China's urbanization development policy, which is to "Strictly Control the Size of Big Cities, Properly Develop Medium-sized Cities, and Actively Develop Small Cities". The agglomeration development is a typical feature of producer services. Large cities have the economy-of-scale effect of urban development and industrial development, while small and medium-sized cities are more suitable for the service radiation of large cities. In most foreign countries, the producer services are concentrated in large cities. China's urbanization strategy should be in line with the industrial development strategy and should not place undue emphasis on such things as strictly controlling the size of big cities and actively developing small towns. Instead, the coordinated development of large, medium and small cities and towns should be promoted. We should create conditions to build urban clusters with large cities and megacities as the core, strengthen the urban agglomeration effects of producer services, expand the supply market and promote the radiating effects of employment.

3) The Technical Progress and the Innovation Capacity Affect the Supply and Employment of Producer Services. The technical progress is an inexhaustible driving force for the development of producer services, but it plays as a double-edged sword in terms of employment. In the short term, the technical progress may lead to the replacement of original industrial sectors and original jobs. The capacity of capital to absorb labor decreases and employment is crowded out. However, the technical progress can bring about the development of new sectors. The improvement of labor productivity can greatly save costs, reduce product prices and expand sales scale in the long run, so as to realize industrial development and increase the demand for labors. At present, the shortage of talents leads to the shortage of the technical progress and the innovation capacity, especially in the finance, logistics, information and telecommunications industries. The service industry requires employees to have differentiated knowledge structures and thinking modes on the basis of a certain knowledge density, and generates synergy and economy-of-scale effects in the process of technology exchange and knowledge sharing. Furthermore, there is a lack of in- 
centive mechanism for the technical progress and service innovation of producer services in China. "Innovation being too easy to copy and imitate" is the biggest obstacle. The first reason is that the intangible nature of innovative service products is difficult to be protected through licensing or intellectual property rights and other tools. Secondly, China's existed laws and regulations are not perfect, lack of effective protection system for service innovations, and cannot effectively maintain the market position and legitimate rights and interests of innovation subjects, which has hurt the enthusiasm of enterprises for continuous innovations and has affected the innovation development and employment of the industry.

\section{Empirical Analysis}

The factors restricting the development and employment of producer services in China are analyzed from the perspectives of demand and supply respectively. However, whether the influence of these factors is significant, which influencing factors are positive and which influencing factors are negative, all need to be evaluated by the empirical test. Hence, the theoretical model and the econometric model are constructed to carry out empirical analysis.

\subsection{Theoretical Model}

The development and employment growth of producer services are the result of multiple factors of supply and demand. Changes in any element will, to some extent, play a positive role in promoting or negatively hindering. In this part, a theoretical model is established to reflect the interrelationship among various influencing factors of producer services employment. In this model, economic development mode, institutional factors, market mechanism, policy factors and technical progress are the main factors restricting demand and supply. They restrict the creation of jobs and employment growth by restricting the development of producer services (Figure 1).

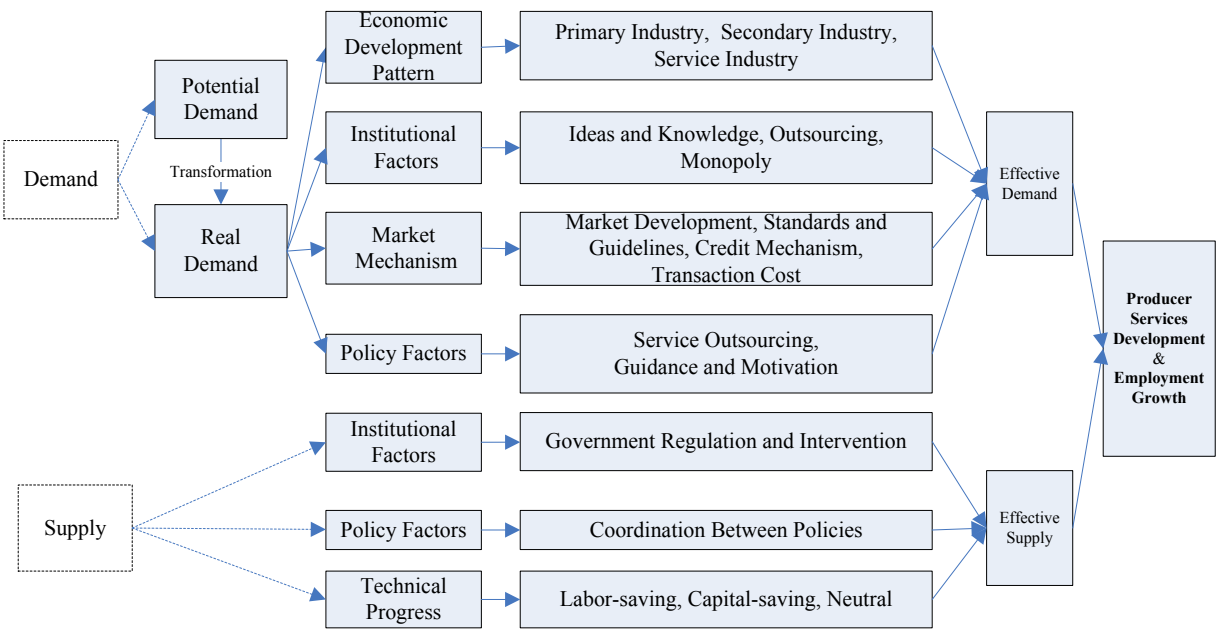

Figure 1. Theoretical model of influencing factors of producer services employment. 


\subsection{Variables Analysis}

1) The Representative Indicator of Economic Development Pattern This paper uses" the ratio between the added value of the service industry and the secondary industry", which is highly recognized internationally, to represent the structural characteristics of Chinese economy. Furthermore, there is a significant and stable positive correlation between the employment proportion of the service industry and GDP per capita, namely, the employment proportion of the service industry gradually increases with the increase of GDP per capita [15]. In this paper, "GDP per capita" is selected as the representative indicator of the economic development level.

2) Representative Indicator of Institutional Factors This paper uses "trade dependence" and "foreign capital dependence", two highly recognized indicators of the economic openness, to measure and analyze the influence of institutional factors on producer services employment.

3) Representative Indicator of Market Mechanism By introducing the relevant indicators of the transformation of government functions into the analysis of influencing factors, we can better measure the impact of the transformation on the employment of producer services. The index selected in this paper is "the proportion of government expenditure in GDP".

4) Representative Indicator of policy The acceleration of urbanization has shifted the labor force from the traditional inefficient primary industry to the modern efficient secondary industry and service industry. On the one hand, the process of urbanization is the process of industrial structure optimization, and on the other hand, it is also the manifestation of employment structure upgrading. This paper uses the "urbanization rate" to measure and analyze the impact of policy factors on producer services employment.

5) Representative Indicator of Technical Progress Technical progress can be divided into labor-saving, capital-saving and neutral technical progress. Labor-saving type will generate employment crowding out effect, while capital-saving type will generate employment promotion. Since it is impossible to separate the two factors, this paper chooses two indicators, "labor productivity" and "capital production ratio" of service industry, to measure the factors of technical progress.

\subsection{Econometric Model}

The multiple-linear regression model is most commonly used in the analysis of influencing factors. In the study of practical problems, the change of dependent variables is affected by multiple factors, so it is necessary to use multiple influencing factors as independent variables to explain the change of the dependent variable and establish a multiple regression model. If let the employment of producer services be $Y$, the independent variables determined by the above analysis are $X_{1}, X_{2}, \ldots X_{8}$, as shown in Table 1 , the model is constructed as follows:

$$
Y=\beta_{0}+\beta_{1} X_{1}+\beta_{2} X_{2}+\beta_{3} X_{3}+\beta_{4} X_{4}+\beta_{5} X_{5}+\beta_{6} X_{6}+\beta_{7} X_{7}+\beta_{8} X_{8}+\mu
$$


Table 1. Variables of the regression model.

\begin{tabular}{|c|c|c|}
\hline Variables (D/S) & Symbol & Description \\
\hline Employment & $Y$ & Number of People Employed in Producer Services \\
\hline GDP Per Capita (D) & $X_{1}$ & Economic Development Level (GDP/Population) \\
\hline Composition of Industry (D) & $X_{2}$ & $\begin{array}{l}\text { Economic Development Pattern (Added Value of the } \\
\text { Service Industry/Added Value of the Secondary Industry) }\end{array}$ \\
\hline Trade Dependence $(\mathrm{D}+\mathrm{S})$ & $X_{3}$ & Institutional Factor (Trade Value/GDP) \\
\hline $\begin{array}{l}\text { Foreign Capital Dependence } \\
\qquad(\mathrm{D}+\mathrm{S})\end{array}$ & $X_{4}$ & $\begin{array}{l}\text { Institutional Factor (Actual Utilization of Foreign } \\
\text { Capital/GDP) }\end{array}$ \\
\hline $\begin{array}{l}\text { Proportion of Government } \\
\text { Expenditure (D) }\end{array}$ & $X_{5}$ & Market Mechanism (Government Expenditure/GDP) \\
\hline Urbanization Rate (S) & $X_{6}$ & Policy Factor (Urban Population/Total Population) \\
\hline $\begin{array}{l}\text { Service Industry Labor } \\
\text { Productivity (S) }\end{array}$ & $X_{7}$ & $\begin{array}{l}\text { Technical Progress (Added Value of the Service } \\
\text { Industry/Service Industry Employment) }\end{array}$ \\
\hline $\begin{array}{l}\text { Service Industry capital } \\
\text { production ratio }(\mathrm{S})\end{array}$ & $X_{8}$ & $\begin{array}{l}\text { Technical Progress (Added Value of the Service } \\
\text { Industry/Service Industry Fixed Assets Investment ) }\end{array}$ \\
\hline
\end{tabular}

In formula (1), $\beta_{0}$ is the constant term, and $\beta_{1}, \beta_{2}, \cdots \beta_{8}$ are the regression coefficients. $\beta_{1}$ is the influence effect of each unit $X_{1}$ increase on $Y$ when other independent variables are fixed, namely, the partial regression coefficient of $X_{1}$ on $Y$.

\subsection{Data Description}

The data are derived from China Statistical Yearbook (2000-2018) published by the National Bureau of Statistics. According to National Economy Industry Classification (GB/T 4754-2017) and Statistical Classification of Producer Services (2019), the classification of producer services include the provision of $R \& D$ and other technical services for production activities, cargo transportation, general aviation production, warehousing, postal service and express delivery services, information services, financial services, energy saving and environmental protection services, productive rental service, business services, human resources management, education and vocational training services, wholesale and trade brokerage services, production support services. According to the research objectives established and to be achieved, the Service Industry Statistical Reporting System of the national bureau of statistics is referenced. It is found that there is no relationship between the number of urban non-private sector employees and the number of urban private sector employees. Therefore, this paper added them together as the number of people employed in producer services.

In order to make the research feasible, the data are standardized in this paper. For example, the GDP deflator was used to adjust the added-value of the industry to eliminate the impact of inflation. Other relevant notes to be made are followed. Firstly, the time span of the data is moderate, and the data distribution is from 2000 to 2017. Secondly, the objectivity and normalization of data are guaranteed. The original data used are all from the statistical bulletin of national 
economic and social development of provinces, regions and cities published by the official website of the national bureau of statistics, as well as the statistical yearbook. Thirdly, due to the failure to obtain the corresponding data of individual indicators, approximate processing is carried out in the calculation process, but it does not affect the integrity and objectivity of the empirical test. Fourthly, the data used in this paper do not include Hong Kong, Macao and Taiwan.

\subsection{Empirical Test}

1) Logarithmic Processing of Data The units of variable value vary greatly, and heteroscedasticity may exist. In order to avoid this problem, the logarithmic processing of all variable data is carried out and the estimated equation is:

$$
\begin{aligned}
L N Y= & C(1)+C(2) * L N X_{1}+C(3) * L N X_{2}+C(4) * L N X_{3}+C(5) * L N X_{4} \\
& +C(6) * L N X_{5}+C(7) * L N X_{6}+C(8) * L N X_{7}+C(9) * L N X_{8}
\end{aligned}
$$

2) Correlation Analysis of Variables Multicollinearity may occur among variables. To avoid this problem, the correlations between variables are analyzed before using the multiple-linear regression model for estimation, and the results are shown in Table 2.

In multiple-linear regression analysis, how many explanatory variables should be introduced into the model was studied. As shown in Table 2, explanatory variables $L N X_{1}, L N X_{2}, L N X_{3}, L N X_{6}$ and $L N X_{7}$ are highly correlated, with correlation coefficients of $0.95,0.89,0.85,0.89$ and 0.73 respectively. The model may have multicollinearity problems, which makes it difficult for $L N Y$ to be well explained by independent variables. Therefore, Stepwise Least Squares strategy was adopted in multivariate regression analysis. It is based on forward screening strategy combined with backward screening strategy to determine again whether there are variables that should be eliminated after each variable enters the equation. At each stage of introducing variables, the stepwise screening strategy provides an opportunity to eliminate insignificant variables.

3) Multiple Regression Analysis Eviews10.0 was used to evaluate and solve the multiple-regression model. Stepwise Least Squares strategy was adopted as the regression method, and the results are shown in Table 3.

The regression expression can be obtained from the operation results in Table 3:

$$
\begin{aligned}
L N Y= & -1.4312+1.1479 * L N X_{1}+0.7993 * L N X_{2}-0.5101 * L N X_{3} \\
& -0.1718 * L N X_{5}-0.9903 * L N X_{7}
\end{aligned}
$$

In Equation (3), t-statistics pass the hypothesis test with significance level of 0.05 , indicating that $X_{1}, X_{2}, X_{3}, X_{5}$ and $X_{7}$ have significant influences on the employment of producer services. The coefficients of R-squared (0.9789) and adjusted R-squared (0.9770) are close to 1, indicating that the model fits well. The associate probability of F-statisticis 0.0000 , which reflects that the variables are highly linear, the overall statistics of the regression equation are significant, and the explanatory ability is strong. 
Table 2. Correlations between variables.

\begin{tabular}{lccccccccc}
\hline & $L N Y$ & $L N X_{1}$ & $L N X_{2}$ & $L N X_{3}$ & $L N X_{4}$ & $L N X_{5}$ & $L N X_{6}$ & $L N X_{7}$ & $L N X_{8}$ \\
\hline$L N Y$ & 1.0000 & 0.9501 & 0.8915 & 0.8520 & -0.3910 & -0.3511 & 0.8972 & 0.7352 & 0.6500 \\
$L N X_{1}$ & 0.9501 & 1.0000 & 0.8135 & 0.8731 & -0.4923 & -0.1999 & 0.9302 & 0.8341 & 0.5492 \\
$L N X_{2}$ & 0.8915 & 0.8135 & 1.0000 & 0.8621 & -0.5993 & -0.1702 & 0.8933 & 0.5112 & 0.5033 \\
$L N X_{3}$ & 0.8520 & 0.8731 & 0.8621 & 1.0000 & -0.5523 & -0.2571 & 0.8913 & 0.6021 & 0.4909 \\
$L N X_{4}$ & -0.3910 & -0.4923 & -0.5993 & -0.5523 & 1.0000 & -0.4952 & -0.7910 & -0.4971 & 0.1603 \\
$L N X_{5}$ & -0.3511 & -0.1999 & -0.1702 & -0.2571 & -0.4952 & 1.0000 & 0.0299 & 0.0629 & -0.6991 \\
$L N X_{6}$ & 0.8972 & 0.9302 & 0.8933 & 0.8913 & -0.7910 & 0.0299 & 1.0000 & 0.7991 & 0.4075 \\
$L N X_{7}$ & 0.7352 & 0.8341 & 0.5112 & 0.6021 & -0.4971 & 0.0629 & 0.7991 & 1.0000 & 0.3926 \\
$L N X_{8}$ & 0.6500 & 0.5492 & 0.5033 & 0.4909 & 0.1603 & -0.6991 & 0.4075 & 0.3926 & 1.0000 \\
\hline
\end{tabular}

Table 3. Multiple regression results.

\begin{tabular}{ccccc}
\hline \multicolumn{5}{c}{ Selection method: Stepwise forwards } \\
\hline \multicolumn{4}{c}{ Stopping criterion: p-value } & \\
\hline Variable & Coefficient & Std. Error & t-Statistic & Prob. $^{*}$ \\
\hline C & -1.4312 & 1.8977 & -0.6919 & 0.3342 \\
$L N X_{1}$ & 1.1479 & 0.2001 & 4.5310 & 0.0000 \\
$L N X_{2}$ & 0.7993 & 0.1907 & 2.3090 & 0.0011 \\
$L N X_{3}$ & -0.5101 & 0.1002 & -3.9102 & 0.0003 \\
$L N X_{5}$ & -0.1718 & 0.0652 & -1.1792 & 0.0209 \\
$L N X_{7}$ & -0.9903 & 0.2241 & -2.0011 & 0.0113 \\
R-squared & 0.9789 & Mean dependent var & 6.7319 \\
Adjusted R-squared & 0.9770 & S.D. dependent var & 0.3002 \\
S.E. of regression & 0.0521 & Akaike info criterion & -2.1190 \\
F-statistic & 210.2213 & Durbin-Watson stat & 1.9990 \\
Prob (F-statistic) & 0.0000 & & \\
\hline
\end{tabular}

4) Heteroscedasticity Test Firstly, the graphic method was used. The scatter diagram of RESID generated by regression and dependent variable $L N Y$ is shown in Figure 2. The microscopic scatter diagram shows that the absolute value of residual sequence has no obvious variation rule and its distribution is relatively random, so it can be preliminarily judged that heteroscedasticity does not exist.

Secondly, the "Heteroskedasticity Test: White" was applied to further test the existence of heteroscedasticity. As shown in Table 4, the White statistic (Obs ${ }^{\star}$ $\mathrm{r}$-squared) is 25.3316 , and its associated probability Chi-square (18) is 0.4518 , greater than 0.05 . Therefore, the original hypothesis is accepted at the significance level of 5\%, indicating that there is no heteroscedasticity in this model.

5) Serial Correlation LM Test Breusch-Godfrey Serial Correlation LM Test (Table 5) showed that $\mathrm{Obs}^{\star} \mathrm{R}$-squared is 2.5625 and prob. Chi-square (2) is 0.2799 , 


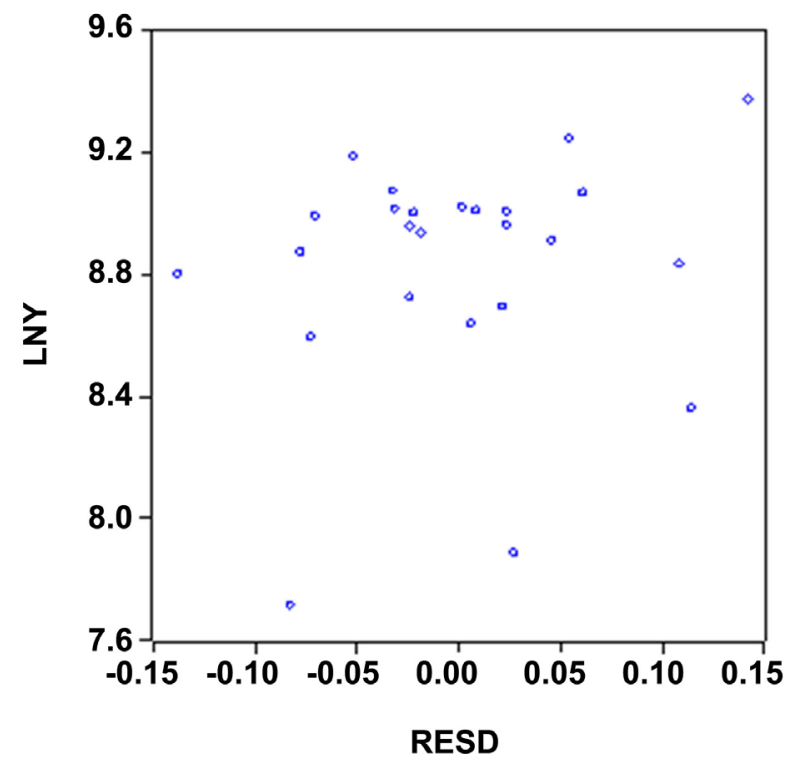

Figure 2. Scatter diagram of RESID and $L N Y$.

Table 4. Heteroskedasticity test: white.

\begin{tabular}{cccc}
\hline F-statistic & 1.2711 & Prob. F(18, 4) & 0.3909 \\
Obs $^{*}$ R-squared & 25.3316 & Prob. Chi-Square (18) & 0.4518 \\
Scaled explained SS & 10.1971 & Prob. Chi-Square (18) & 0.9163 \\
\hline
\end{tabular}

Table 5. Breusch-Godfrey serial correlation LM test.

\begin{tabular}{cccc}
\hline F-statistic & 0.9142 & Prob. F $(2,16)$ & 0.3179 \\
Obs ${ }^{\star}$ R-squared & 2.5625 & Prob. Chi-Square (2) & 0.2799 \\
\hline
\end{tabular}

which is greater than 0.05 , indicating that there is no sequence correlation in the model.

\subsection{Interpretation of the Result}

In the selected period from 2000 to 2017, foreign capital dependence (D + S), urbanization rate $(S)$ and capital production rate $(S)$ of the service industry have no significant influences on the employment of producer services. Explanatory variables with significant influence include positive influences, i.e. GDP per capita (D) and the ratio of added-value of the service industry and secondary industry (D), which play a positive role in promoting producer services employment. It also includes negative impacts, namely, the labor productivity of the service industry $(S)$, the trade dependence $(D+S)$ and the proportion of government fiscal expenditure (D), which crowd out the employment of producer services and hinder employment growth. The specific results are shown below.

1) The economic development level (D) plays the most obvious role in promoting producer services employment. Other factors remain unchanged, when GDP per capita increases by $1 \%$, the employment of producer services increase 
by $1.14 \% .2$ ) The influence of economic development pattern (D) is ranked the second place. Every $1 \%$ increase in the share of the service sector relative to the added-value of the secondary industry boosts the employment of producer services by $0.79 \%$. 3) The increase of labor productivity (S) brought by technical progress has a negative impact on the employment of producer services. For every $1 \%$ increase in the labor productivity of the service industry, the employment of producer services is reduced by $0.99 \%$. Technical progress has brought about the crowding out and substitution of labor. 4) The influence of trade dependence $(D+S)$ on producer services employment is negative, and the correlation coefficient is -0.5101 . When other factors remained unchanged, the employment of producer services decreases by $0.51 \%$ for every $1 \%$ increase in trade dependence. 5) The ratio of government expenditure to GDP (D) has a negative influence on producer services employment, but the correlation coefficient is -0.1718 , which is relatively small. It indicates that for every $1 \%$ increase in government expenditure, the employment of producer services decreases by $0.17 \%$.

\section{Conclusions}

Regarding the research theme as the core, the factors influencing the development and employment of producer services from the perspectives of demand and supply are analyzed and a theoretical model of the influencing factors is constructed. The significance and difference of the influencing factors are empirically tested through the construction of an econometric model, and the relevant conclusions are drawn as follows.

Among the factors promoting the employment of producer services, the economic development level plays the most important role. Raising the level of national economic development and personal income can greatly increase the demand and consumption of producer services and achieve coordinated growth of the economy and employment. Economic development pattern is ranked the second place in promoting producer services employment. As a sub-industry within the service sector, the employment growth of producer services is a manifestation of the high-level employment structure, and its employment must be supported and guaranteed by the development of the service industry. Therefore, the government should strengthen policy supports for the development of the service industry, especially for producer services at the high end of the value chain, which is of great help to solve the current employment problems.

Among the factors hindering the employment of producer services, the improvement of labor productivity, brought by technical progress, results in the most significant crowding out and substitution for labors. In the long run, though, higher productivity can save production costs, lower prices and expand sales, thus stimulating production and employment. However, necessary measures should be taken to alleviate employment pressures in the short term. Therefore, in the choice of development paths, we should give full consideration to the factor endowments structure in line with China's current national conditions, and 
give full play to the compensation effects of technical progress driving employment growth. Secondly, the degree of openness measured by trade dependence has a negative influence on producer services employment. Increased trade dependence brings up crowding out effects on producer services employment, fully shows that China's producer services are mainly inward-oriented in driving employment. Finally, the increase of government expenditure, which is influenced by the market mechanism, leads to the decrease of the employment of producer services. Therefore, the government should moderately reduce the investment intensity and reduce the degree of intervention in the market. It is necessary to separate government and enterprises, government capitals and government affairs, reduce administrative monopoly as much as possible, and introduce market mechanism into non-natural monopoly business departments, which can greatly reduce the negative influences on the employment of producer services. The government should relax the administrative control of the factor markets, such as the control of wages and the price of capital factors. It is necessary to fully let the market mechanism play its role, which can greatly enhance the ability of enterprises to independently determine factor prices and promote the normal play of the labor market mechanism.

\section{Funding}

1) The Employment Effects of Producer Services in Beijing, Beijing Municipal Education Commission Project (SM201610017001). 2) The Employment Supports for Land-expropriated Farmers of Daxing District in Beijing-from the Perspective of Three-dimensional Capital, Beijing Social Science Foundation Research Base Project (16JDSRC008). 3) The Employment Effects of Producer Services in Beijing, Beijing URT Project (2018J00210).

\section{Conflicts of Interest}

The authors declare no conflicts of interest regarding the publication of this paper.

\section{References}

[1] Jia, H., Liu, L. and Liu, B. (2019) Employment Contribution of Producer Services-A Case Study of Beijing. American Journal of Industrial and Business Management, 9, 1581-1595. https://doi.org/10.4236/ajibm.2019.97104

[2] Kuznets (1960) Development and the Service Economy in the Third World. Praeger Publishers, New York and London.

[3] Beyers, W.B. (1999) There's Gold in Them There Producer Services. Policy Options, $11,36-39$.

[4] Juleff, H. and Walker, G.M. (1999) Unemployment Insurance: Global Evidence of its Effects on Unemployment. Praeger Publishers, New York and London.

[5] Bishop, P. (2009) Spatial Spillovers and Employment Growth in the Service Sector. The Service Industries Journal, 6, 791-803. https://doi.org/10.1080/02642060902749310 
[6] Lu, L.W. (2011) Measures to Improve the Employment Absorption Capacity of the Tertiary Industry in the Yangtze River Delta Region. Economic Review Journal, 5, 51-54.

[7] Che, F. and Che, G.J. (2012) An Empirical Analysis of the Impact of Producer Services on the Employment of Urban Subsistence Allowance Recipients-A Case Study of Beijing. Academic Exploration, 7, 65-69.

[8] Zeng, S.H. and Ma, M. (2013) Empirical Research on Low Employment Absorption Capacity and Influencing Factors of Producer Services in China under the Background of High Growth. Industrial Economic Review, 4, 5-12.

[9] Zhang, Y.J., Wu, L.Y. and Qin, B. (2017) Measurement Method of Spatial Agglomeration and Influencing Factors of Producer Services in Beijing Based on Continuous Plane Method. Journal of Central University of Finance and Economics, 9, 111-118.

[10] Li, L.S., Yang, J. and Shi, X.A. (2018) Can "Internet+" Promote the Employment of Producer Services in China. Forum on Science and Technology, 11, 63-70.

[11] Lv, Z., Liu, Y. and Wang, Q. (2006) Strategic Choices of Producer Services Development in China from the Perspective of Industrial Interaction. China Industrial Economics, 8, 5-12.

[12] Gao, C.S. and Li, S.T. (2007) Producer Services in China: Analysis of Content Development and Structure Based on China's Input and Output Table from 1987 to 2002. Modern Economic Research, 8, 68-72.

[13] Li, J.F. (2005) Research on the Development of China's Trtiary Industry. People's Publishing House, Beijing.

[14] Li, G.L. (2014) Employment Ability Development of Land-Lost Farmers from the Perspective of Sustainable Livelihood. Development Research, 1, 27-30.

[15] Xie, D.D. (2009) The Relationship between Service Industry Development and per Capita Income: An Empirical Study Based on Quantile Regression. Contemporary Finance and Economics, 8, 80-84. 